\title{
Chapter 9 \\ Simulation and Optimization \\ of Renewable Energy Hybrid Power \\ System for Semonkong, Lesotho
}

\author{
Leboli Z. Thamae $\mathbb{D}$
}

\begin{abstract}
Rugged hills and mountain ranges with sparsely populated rural villages characterize the vast majority of Lesotho's landscape, making it prohibitively expensive and financially unviable to connect these remote villages to the national electricity grid. This lack of access to electricity has hampered many social and economic developments due to insufficient provision of much-needed power to homes, schools, police stations, clinics and local businesses. This paper proposes a renewable energy hybrid power generation system for one such remote town of Semonkong, in Maseru district, Lesotho. The study models, simulates and optimizes the hybrid power system using the load profile of Semonkong town and the available renewable resources data of solar radiation, wind speeds and water flow rates from the nearby Maletsunyane River. The HOMER software is used to provide an optimal system configuration in terms of the minimum levelized cost of electricity (LCOE) and the maximum renewable energy fraction, based on various renewable and alternative energy sources of solar photovoltaic, wind turbine, mini-hydro turbine, diesel generator and battery storage. Sensitivity analysis on solar radiation, wind speed, stream flow, diesel price and energy demand is undertaken to evaluate the feasibility of a completely-renewable power system suitable for this remote area application. Simulation results for the isolated optimized hydro/wind/PV/diesel/battery hybrid system configuration achieves LCOE of US $\$ 0.289 / \mathrm{kW}$ at a renewable energy fraction of 0.98 . Thus, the diesel generator will always be required to augment power supply for Semonkong especially during the dry and cold winter months of May to September when the energy demand is at its peak but the solar radiation and stream flow are at their lowest.
\end{abstract}

Keywords Renewable energy - Solar photovoltaic • Wind energy Mini-hydropower • Optimal hybrid system

\footnotetext{
L. Z. Thamae $(\bowtie)$

Department of Physics and Electronics, National University of Lesotho, Rome 180, Lesotho e-mail: zl.thamae@nul.ls; thamae@gmail.com
}

L. Z. Thamae

Energy Research Centre (ERC), National University of Lesotho, Rome 180, Lesotho

(C) The Author(s) 2018

M. Mpholo et al. (eds.), Africa-EU Renewable Energy Research and Innovation

Symposium 2018 (RERIS 2018), Springer Proceedings in Energy,

https://doi.org/10.1007/978-3-319-93438-9_9 


\subsection{Introduction}

It has been estimated that around 600 million people in Sub-Saharan Africa lived without access to electricity at all [1]. In Lesotho for instance, around $60 \%$ of the population, mostly in isolated rural areas, currently do not have access to electricity. Extension of the grid to such areas is highly costly and often not feasible, at least in the short to medium term [2]. In such cases, mini-grids based mainly on locally-available renewable resources for decentralized hybrid power systems and household energy solutions become handy in provision of electricity for households and local businesses. Hybrid mini-grids are a mature and reliable solution that combines at least two different kinds of technologies for power generation to be used for lighting, communications, water supply or motive power [3]. A small town of Semonkong, located in Lesotho's Maseru district, is one such rural village that is currently supplied with a hydro-diesel hybrid power system using a village-wide distribution network, which is at least $70 \mathrm{~km}$ away from the nearest grid. Due to the challenging mountainous terrain and difficult access for transmission lines, grid extension to Semonkong will come at a very high cost.

Semonkong power station's mini-hydro component is a run-of-river system with a small dam/reservoir built on the Maletsunyane River that passes through the village. It uses a vertical Francis turbine rated at $180 \mathrm{~kW}$ with a head of $19 \mathrm{~m}$. The backup diesel generator is rated at $500 \mathrm{kVA}$ (or $400 \mathrm{~kW}$ at 0.8 power factor). The peak electricity demand in August 2017 has been recorded as $198 \mathrm{~kW}$ with an average energy demand of 3.6 MWh/day. For seasons with good rains in the past, the hydro turbine generation was able to meet the local electricity demand, even though in recent years the growing peak demand at around $200 \mathrm{~kW}$ has exceeded the mini-hydro turbine capacity. During the 2012/13, the annual energy production for Semonkong power station amounted to about $505 \mathrm{MWh}$ (or $1.383 \mathrm{MWh} /$ day), with $89 \%$ coming from hydro and $11 \%$ from diesel, the latter requiring an actual cost of M0.557 million [4], which translates to M9.84/kWh, equivalent to US\$0.70/kWh. ${ }^{1}$ Comparing this value with the approved electricity tariffs during the same year, the unit tariffs for general purpose and domestic customers were M1.01/kWh (or US $\$ 0.07 / \mathrm{kWh}$ ) and M0.90/kWh (or US $\$ 0.06 / \mathrm{kWh}$ ) respectively [4]. It can therefore be deduced that, excluding labour and operation and maintenance $(\mathrm{O} \& \mathrm{M})$ costs for the isolated Semonkong mini-grid, the diesel-generated unit of energy was on average 10 times more expensive than its selling price. Since electricity tariffs are the same for these rural customers as they are for the grid-connected ones despite dramatically different costs, this has cross-subsidy implications and increases the overall price for all consumers in the country.

Another known challenge of diesel generator stations is that it is difficult to distribute the fuel especially in rural and remote mountainous areas. It is against this background that $100 \%$ diesel-fuelled mini-grids will prove to be more expensive on a lifetime basis than hybrid ones, strengthening the case for off-grid electrification

\footnotetext{
${ }^{1}$ Assuming US $\$ 1.00=$ M $14.00($ LSL) in 2012/13.
} 
using a combination of locally-available renewable resources of solar, wind and hydro where feasible, with diesel generator and battery bank as back-up components [5]. This study therefore seeks to evaluate the type of renewable energy technologies (RETs) that are mostly favourable for the study area of Semonkong town, in Lesotho. It will answer research questions such as whether it is feasible and cost-effective to supply the town completely from renewable energy; whether it is critical to add battery bank and diesel generator back-up systems; and whether the hybrid power system design will meet the growing electric demand. The data obtained for the load profiles, renewable and alternative resources, and components costs are briefly described under the methodology in Sect. 9.2, followed by the results and discussions of the proposed full hybrid PV/wind/hydro/diesel/battery system configuration, simulation, optimization and sensitivity analysis in Sect. 9.3. The conclusions are summarized in Sect. 9.4.

\subsection{Methodology: Load Profile, Resources and Components}

The main aim of the study is to use HOMER software to evaluate hybrid power system designs for Semonkong using several available RETs incorporating diesel generator and battery back-up systems. The approach engaged in answering the above research questions makes use of HOMER software (which stands for Hybrid Optimization Model for Electric Renewable) [6-8]. As inputs to HOMER, data on electricity load profile and resource availability for the rural town of Semonkong in Lesotho has been collected from several reliable sources [4, 9]. Component costs and performance characteristics have been benchmarked with similar previous studies [3, 5, 7, 8, and 10]. Semonkong is a good case study for off-grid hybrid power system due to one river (Maletsunyane) running through it and having meteorological stations with data available for river flow rates, solar radiation and wind speeds. Its location therefore offers excellent natural conditions for the use of mini-hydro power, solar PV and wind as illustrated in the following sub-sections.

\subsubsection{Load Profile}

A load profile for Semonkong is demonstrated in Fig. 9.1 based on the utility's 2016/17 electricity demand data [9], entered in HOMER with a random variability of $5 \%$. The hourly load consumption shifts throughout the day with peak demand of $212 \mathrm{~kW}$, average load of $150 \mathrm{~kW}$, average energy consumption of $3611 \mathrm{kWh} /$ day and a load factor of $70.9 \%$. 

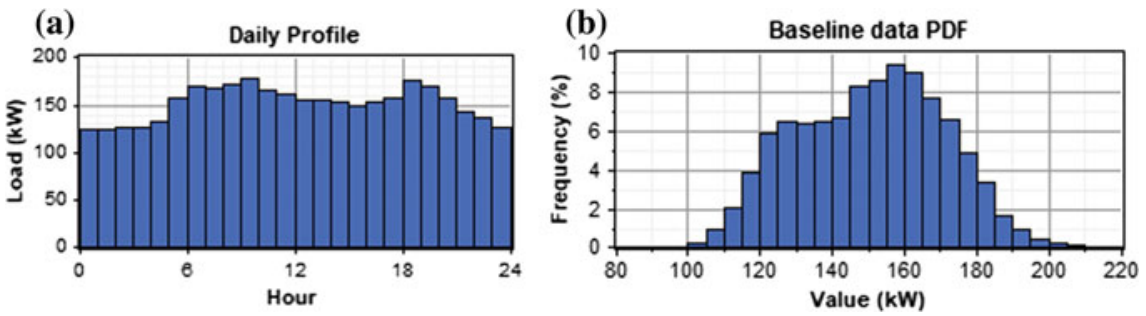

Fig. 9.1 Semonkong's load profile: a Daily profile. b Demand PDF

\subsubsection{Resources and Components}

Figures 9.2, 9.3 and 9.4 graphically illustrate the respective data for renewable resources of river flow rates, solar radiation and wind speeds at the study area. According to Fig. 9.2, there is more water available during the rainy summer months of October to April than during the dry winter months of May to September. The stream flow achieves an annual average of $1095 \mathrm{~L} / \mathrm{s}$. Figure 9.3 indicates daily solar radiation with annual average global horizontal radiation of $5.43 \mathrm{kWh} / \mathrm{m}^{2} / \mathrm{d}$ and average clearness index of 0.61 . Similar to the hydro resource, the insolation is higher during the summer months but slightly weaker (about $4 \mathrm{kWh} / \mathrm{m}^{2} / \mathrm{d}$ or lower) in dry winter months of May to July while the clearness index is higher. The monthly average wind speed illustrated in Fig. 9.4 is particularly stronger between August and October and it has a Weibull probability distribution function (PDF) with a shape factor of $\mathrm{k}=2.03$. The annual average wind speed is about $6.85 \mathrm{~m} / \mathrm{s}$, which is higher than the $4-5 \mathrm{~m} / \mathrm{s}$ normally needed to make a wind power system profitable [2].

To enter the components data for HOMER simulation, the existing $180 \mathrm{~kW}$ hydro turbine is modelled with component cost of US $\$ 1790 / \mathrm{kW}$ for the initial capital cost, replacement cost that is $7 \%$ lower, O\&M costs at $2 \%$ of capital cost for a lifetime of 25 years. A solar PV component cost of US $\$ 2822 / \mathrm{kW}$ is used for the capital cost, US $\$ 2500 / \mathrm{kW}$ for replacement and $1.5 \%$ of initial capital for O\&M costs with a projected lifetime of 20 years. Fuhrlander FL30 wind turbine with a rated power of $30 \mathrm{~kW}$ at $12 \mathrm{~m} / \mathrm{s}$ and hub height of $27 \mathrm{~m}$ is used in HOMER with component cost of US $\$ 2120 / \mathrm{kW}$ for both the initial capital and the replacement costs. The O\&M cost is taken to be $10 \%$ of the initial cost and the projected lifetime is 25 years. The $400 \mathrm{~kW}$ rating of the existing diesel generator is used with US $\$ 400 / \mathrm{kW}$ for both capital and replacement costs, US $\$ 1.75 / \mathrm{hr}$ for O\&M costs and US $\$ 0.75 / \mathrm{L}$ diesel price in Lesotho as at November 2017. Battery voltage rating of $6 \mathrm{~V}$ with a nominal capacity of $360 \mathrm{Ah}(2.16 \mathrm{kWh})$ has been chosen for simulation with 4 batteries per string at an initial unit cost and replacement cost of US\$225 and O\&M cost of US\$10. A converter for DC to AC power conversion has also been included at US $\$ 1445 / \mathrm{kW}$ capital and replacement costs and 10\% O\&M costs. 


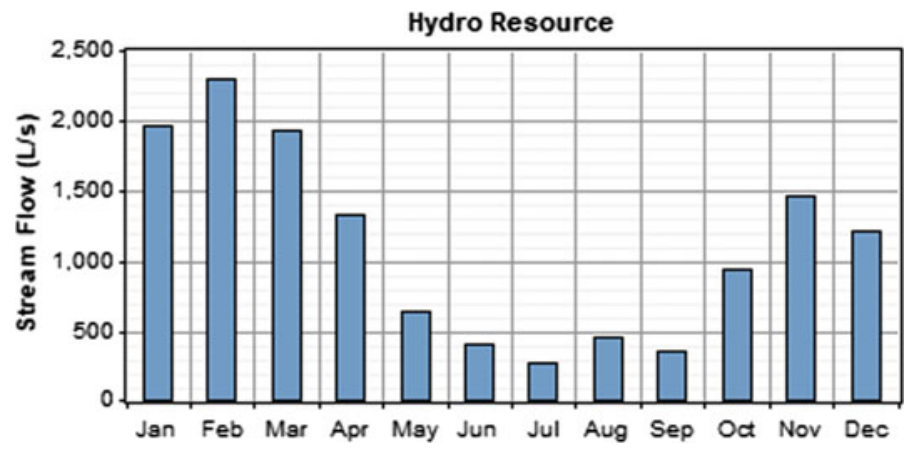

Fig. 9.2 Maletsunyane River's average flow rates

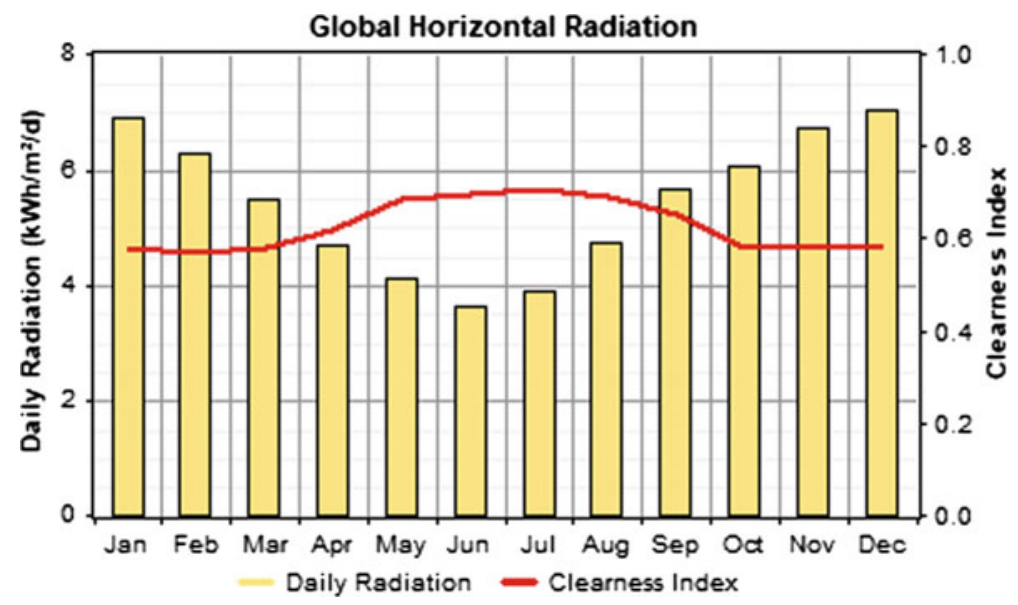

Fig. 9.3 Semonkong's daily solar radiation and clearness index

\subsection{Results and Discussions: Hybrid System Simulation and Optimization}

A hybrid power generation system using the local load profile, resources and components costs from Sect. 2 has been modelled in HOMER. Since the load profile and natural conditions are site specific, the results obtained in the next sub-sections are valid for the study site of Semonkong and should not be extrapolated to other areas. However, the lessons learnt will be applicable to locations with similar settings. 


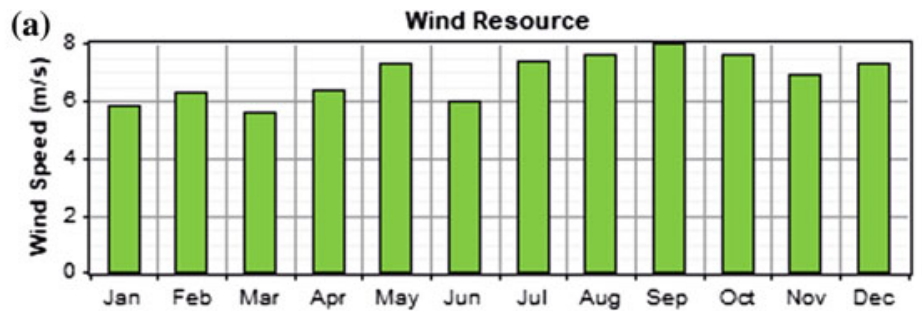

(b) Baseline data PDF

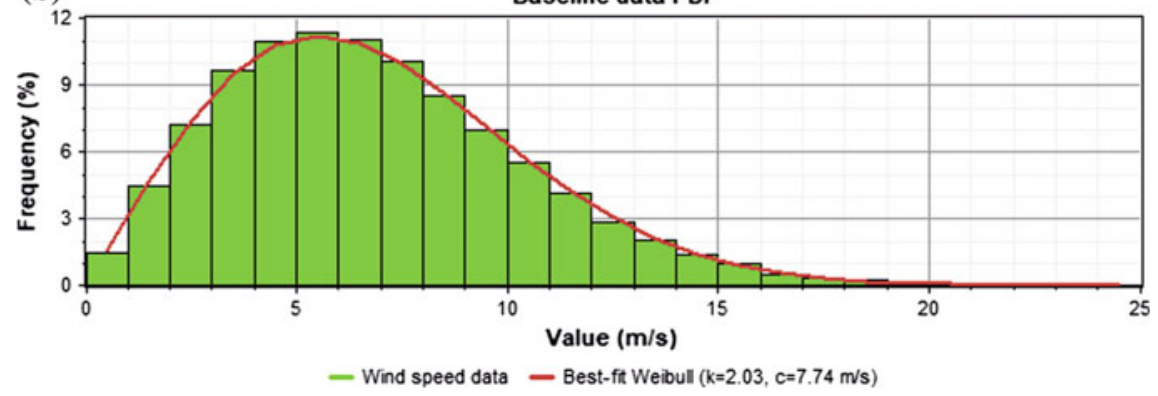

Fig. 9.4 Semonkong's wind resources: a Monthly average wind speeds. b Wind speed PDF

\subsubsection{Simulation Results}

HOMER simulation produces a list of feasible design options or system configurations, ranked by the lowest total net present cost (NPC) as illustrated in Fig. 9.5. Examining each feasible system configuration allows for economic and technical merits evaluation including the LCOE and renewable energy fraction. Other system operational characteristics such as annual power production, annual electric load served, fuel consumption, excess electricity, capacity shortage, unmet electric load and emissions can also be evaluated.

For instance, the simulation results from Fig. 9.5 show that the existing hydro/ diesel hybrid system is ranked bottom as one of the least cost-effective options at US\$0.471/kWh (M6.594/kWh) and 0.66 renewable energy fraction (66\% hydro and $34 \%$ diesel). The hydro component is more effective during the rainy summer season but needs diesel generator support during the dry winter months (compare with Fig. 9.2). This configuration has $26.4 \%$ excess electricity production per annum. The share of renewables needs to be increased to make this hybrid system almost independent of diesel and to lower energy prices over the long term as described in the next sub-section. 


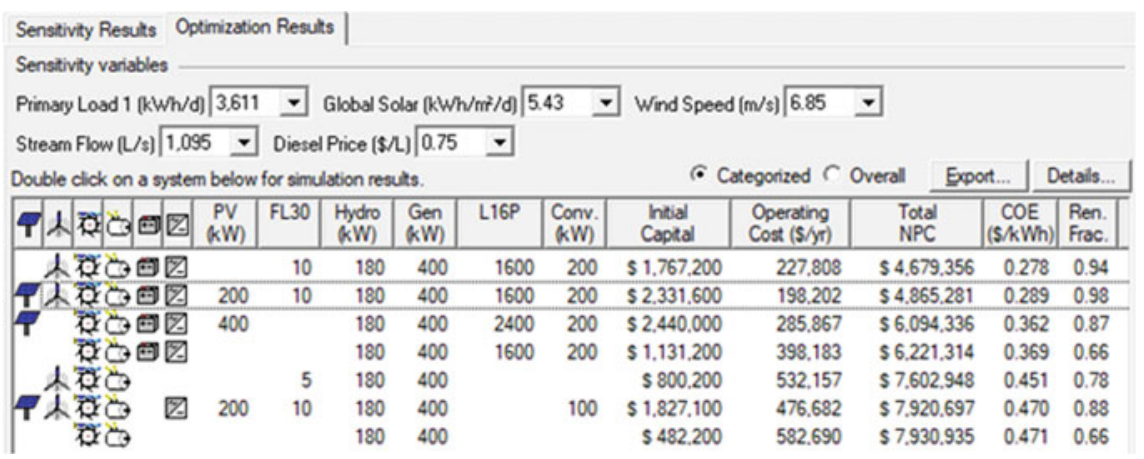

Fig. 9.5 Hybrid power system simulation results

\subsubsection{Optimization Results}

Using the simulation results of Fig. 9.5, the wind/hydro/diesel/battery combination that excludes the solar PV component is the most cost-effective mini-grid solution for Semonkong with LCOE of US $\$ 0.278 / \mathrm{kWh}(\mathrm{M} 3.892 / \mathrm{kWh})$ and a renewable energy fraction of 0.94 . This optimum system architecture will have a total annual energy production of $44 \%$ wind, $50 \%$ hydro and $6 \%$ diesel, with $41.5 \%$ excess annual electricity production. Though the unit cost would be about half compared to the hydro/diesel hybrid above, it will still be more expensive than the current utility's power purchases from the local 'Muela hydro at a subsidized M0.15/kWh (US\$0.011/kWh), imports from South Africa's Eskom at an average of M0.97/kWh (US\$0.069/kWh) and Mozambique's EDM at around M1.50/kWh (US\$0.107/kWh). Even the current 2017/18 respective domestic and general purpose approved tariffs of M1.424/kWh (US\$0.102/kWh) and M1.6/kWh (US\$0.114/kWh) will be less than half of the US\$0.278/kWh LCOE [4].

The second optimal configuration from Fig. 9.5 is the PV/wind/hydro/diesel/ battery hybrid with LCOE of US $\$ 0.289 / \mathrm{kWh}(\mathrm{M} 4.046 / \mathrm{kWh})$ but marginally favourable renewable energy fraction of 0.98 . Figure 9.6 shows its system architecture together with electrical operational characteristics. The annual electric energy production comprises $13 \% \mathrm{PV}, 39 \%$ wind, $45 \%$ hydro and $2 \%$ diesel with an excess annual generation of $48.3 \%$.

One clear deduction from these two most cost-effective results is that it will not be possible to supply Semonkong on RETs only as the diesel generator is always required in any system configuration to meet the local demand. Diesel generator use is critical for quality of service when other RETs are low and unable to meet the demand in winter months of June to September. However, it can be minimized from 6 to $2 \%$ by employing more renewables as in the second option that makes use of all the available natural renewable resources, with half the pollutant emissions but small difference of $3.8 \%$ in LCOE. Hence for the sensitivity analysis in the 


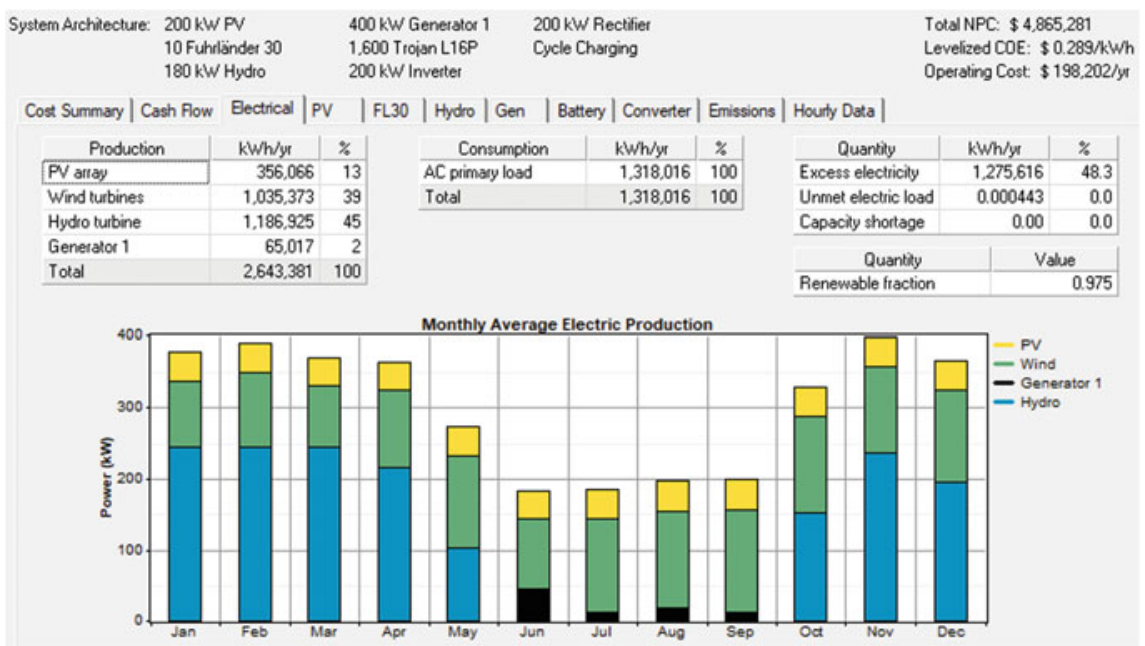

Fig. 9.6 Optimized PV/wind/hydro/diesel/battery hybrid

following sub-section, the two most cost-effective system architectures with and without the PV component are considered.

\subsubsection{Sensitivity Analysis Results}

The sensitivity analysis results for the optimal system with fixed primary load, stream flow and diesel price superimposed with LCOE is illustrated Fig. 9.7. It can be seen that the average local natural conditions of $5.43 \mathrm{kWh} / \mathrm{m}^{2} / \mathrm{d}$ solar radiation and $6.85 \mathrm{~m} / \mathrm{s}$ wind speed lead to LCOE of US $\$ 0.278 / \mathrm{kWh}$ for a hydro/wind/diesel/ battery system configuration indicated by a diamond. This configuration remains dominant regardless of changes in solar radiation and wind speeds. However, for wind speed, the LCOE varies from US $\$ 0.299 / \mathrm{kWh}$ at $6.0 \mathrm{~m} / \mathrm{s}$ to a favourable US $\$ 0.250 / \mathrm{kWh}$ for wind speeds around $8.0 \mathrm{~m} / \mathrm{s}$, regardless of the solar radiation.

Similar sensitivity analysis for the current load $(3611 \mathrm{kWh} / \mathrm{d})$ with decreased stream flow $(900 \mathrm{~L} / \mathrm{s}$ ) and increased fuel price (US\$0.95/L), illustrated in Fig. 9.8 gives the LCOE of about US $\$ 0.285 / \mathrm{kWh}$ for a hydro/wind/diesel/battery system architecture at the average local natural conditions of $5.43 \mathrm{kWh} / \mathrm{m}^{2} / \mathrm{d}$ solar radiation and $6.85 \mathrm{~m} / \mathrm{s}$ wind speed. This architecture becomes the most optimal combination for majority of the conditions, but when the solar radiation goes above $5.6 \mathrm{kWh} / \mathrm{m}^{2} / \mathrm{d}$ for wind speeds between 6.0 and $6.3 \mathrm{~m} / \mathrm{s}$, the hydro/wind/PV/diesel/battery hybrid becomes more cost-effective. For varying solar radiation and wind speeds, the LCOE varies from a maximum of US $\$ 0.311 / \mathrm{kWh}$ when they are respectively at 5.0 $\mathrm{kWh} / \mathrm{m}^{2} / \mathrm{d}$ and $6.0 \mathrm{~m} / \mathrm{s}$ to a minimum of US $\$ 0.255 / \mathrm{kWh}$ at wind speed of $8.0 \mathrm{~m} / \mathrm{s}$. 


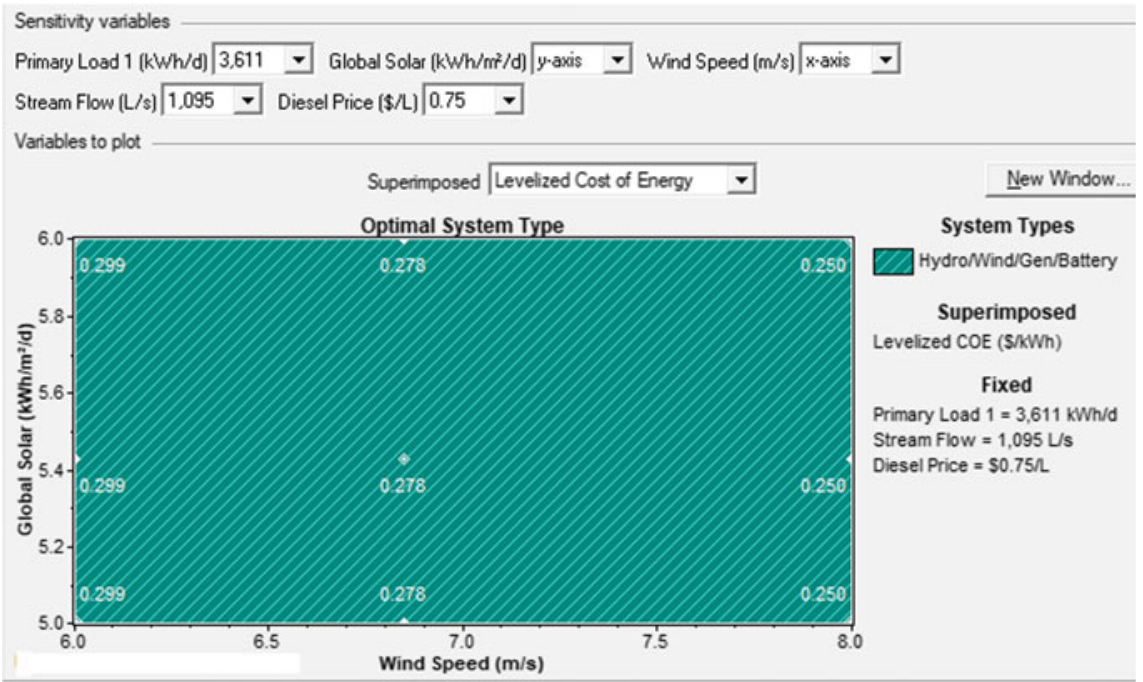

Fig. 9.7 Optimal system with fixed load, stream flow and diesel price

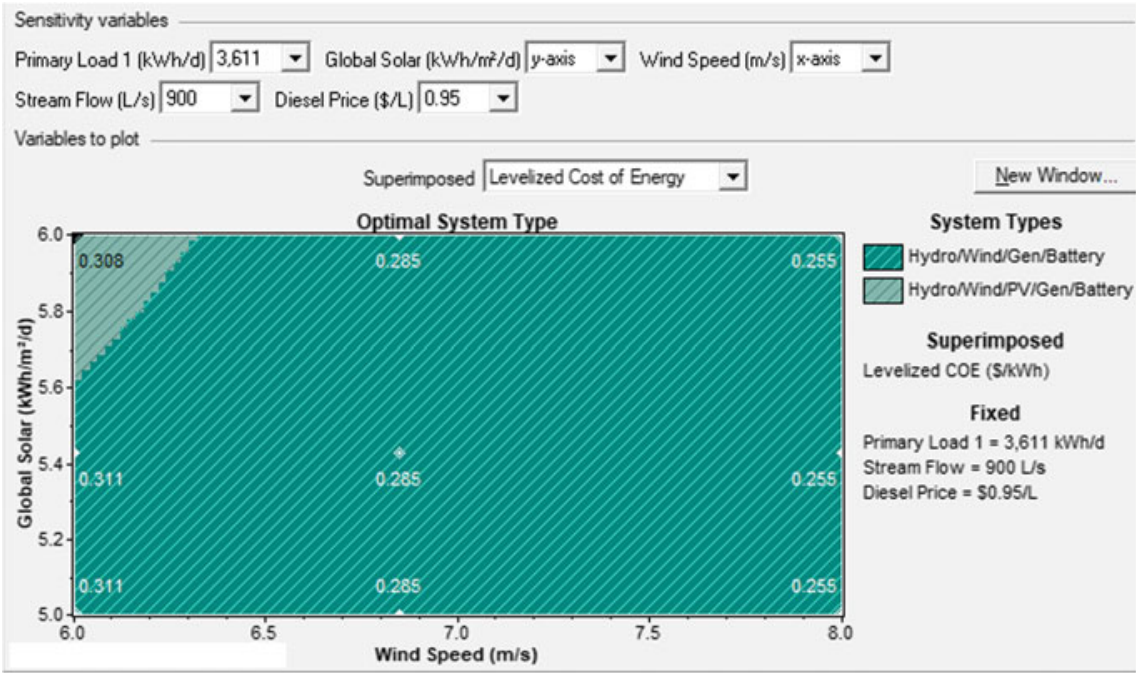

Fig. 9.8 Optimal system with fixed load, decreased stream flow and increased diesel price

The last sensitivity analysis assumes the local demand increase of $30 \%$ to $3960 \mathrm{kWh} / \mathrm{d}$ while the stream flow is still $900 \mathrm{~L} / \mathrm{s}$ with diesel price at US\$0.95/L. The average local conditions of solar radiation at $5.43 \mathrm{kWh} / \mathrm{m}^{2} / \mathrm{d}$ and wind speed at $6.85 \mathrm{~m} / \mathrm{s}$ lead to LCOE of about US $\$ 0.273 / \mathrm{kWh}$ for a hydro/wind/diesel/battery system architecture with slightly reduced renewable fraction of 0.92 and $33.6 \%$ 
excess electricity. Hence the increase in local demand will still be met and a slight $1.8 \%$ reduction in LCOE due to scale, but with the diesel generator's production increases from 6 to $8 \%$ to meet the increased new average demand of $195 \mathrm{~kW}$. The hybrid system architecture integrating the PV component can play a negligible role for solar radiation values above $5.8 \mathrm{kWh} / \mathrm{m}^{2} / \mathrm{d}$ as long as the wind speeds are lower than $6.1 \mathrm{~m} / \mathrm{s}$, leading to LCOE of US $\$ 0.303 / \mathrm{kWh}$. Other solar radiation values and wind speeds at different values lead to maximum LCOE of US $\$ 0.304 / \mathrm{kWh}$ when they are respectively at $5.0 \mathrm{kWh} / \mathrm{m}^{2} / \mathrm{d}$ and $6.0 \mathrm{~m} / \mathrm{s}$ and a minimum of US $\$ 0.246 / \mathrm{kWh}$ for $6.0 \mathrm{kWh} / \mathrm{m}^{2} / \mathrm{d}$ and $8.0 \mathrm{~m} / \mathrm{s}$.

\subsection{Conclusions}

This study has illustrated through HOMER hybrid power system simulation and optimization that technically, hybrid electricity generation using mainly local renewable energy resources can be a cost-effective means of supplying affordable and reliable power for rural communities like Semonkong in Lesotho. When compared with the existing hydro/diesel hybrid at the LCOE of US $\$ 0.471 / \mathrm{kWh}$ and $66 \%$ renewable fraction, a full hydro/wind/PV/diesel/battery hybrid system configuration could lower the costs by $40 \%$ to US $\$ 0.289 / \mathrm{kWh}$ with a higher renewable energy fraction of $98 \%$. Clearly, the diesel generator backup will always be required to ensure reliability and quality of supply when the RETs are low.

The sensitivity analysis results further indicated that due to varying local natural conditions of solar, hydro and wind at the site, LCOE can vary from a minimum of US $\$ 0.250 / \mathrm{kWh}$ to a maximum of US $\$ 0.311 / \mathrm{kWh}$. Increase in demand of around $30 \%$ would still be met by the chosen optimal hybrid system at a slightly reduced renewable fraction of 0.92 . The actual required investment costs for upgrade of the already existing hydro/diesel hybrid station to the full PV/wind/hydro/diesel/battery hybrid system will be mainly on integrating wind turbines, solar PV panels, battery and converter components. Since this particular system is already owned and operated by the national utility, if the grid finally arrives in future, it would just be connected to the grid and augment the national supply.

\section{References}

1. A. Eberhard, K. Gratwick, E. Morella, P. Antmann, Independent Power Projects in Sub-Saharan Africa; Lessons from Five Key Countries (World Bank Group, Washington, D. C, 2016)

2. A.R.E. Report, Hybrid Mini-Grids for Rural Electrification-Lessons Learned (Alliance for Rural Electrification (ARE), Brussels, 2014)

3. S. Baurzhan, G.P. Jenkins, Off-grid solar PV: is it an affordable or appropriate solution for rural electrification in Sub-Saharan African countries? Renew. Sustain. Energy Rev. 60, 1405-1418 (2016) 
4. LEWA, Tariff Determination for LEC (Lesotho Electricity and Water Authority, 2018), http:// www.lewa.org.ls/tariffs/Tariffs_Determinations.php. Accessed 02/03/2018

5. W. Su, Z. Yuan, M.-Y. Chow, Microgrid Planning and Operation: Solar Energy and Wind Energy, in IEEE Power and Energy Society General Meeting, 2010

6. NREL, Getting Started Guide for HOMER Legacy (Version 2.68) (National Renewable Energy Laboratory, Colorado, 2011)

7. D.K. Lal, B.B. Dash, A.K. Akella, Optimization of PV/Wind/Micro-Hydro/Diesel hybrid power system in HOMER for the study area. Int. J. Electr. Eng. Inf. 3, 307-325 (2011)

8. T. Lambert, P. Gilman, P. Lilienthal, Micropower System Modeling with HOMER, Integration of Alternative Sources of Energy (Wiley, Hoboken, 2006)

9. Lesotho Electricity Company, www.lec.co.ls. Accessed 02/03/2018

10. U.S. Magarappanavar, S. Koti, Optimization of Wind-Solar-Diesel Generator Hybrid Power System using HOMER, in International Research Journal of Engineering and Technology, vol. 3(6), 2016

Open Access This chapter is licensed under the terms of the Creative Commons Attribution 4.0 International License http://creativecommons.org/licenses/by/4.0/, which permits use, sharing, adaptation, distribution and reproduction in any medium or format, as long as you give appropriate credit to the original author(s) and the source, provide a link to the Creative Commons license and indicate if changes were made.

The images or other third party material in this chapter are included in the chapter's Creative Commons license, unless indicated otherwise in a credit line to the material. If material is not included in the chapter's Creative Commons license and your intended use is not permitted by statutory regulation or exceeds the permitted use, you will need to obtain permission directly from the copyright holder.

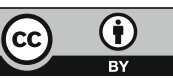

